\title{
Taking A Pulse: \\ Student-Athletes' Descriptors For Their First Semester Of College
}

Jeanne L. Higbee, University of Minnesota, Twin Cities, USA

Jennifer L. Schultz, Metropolitan State University, Minnesota, USA

\begin{abstract}
This paper summarizes the responses of 103 student-athletes enrolled in a first-year experience course when asked, "What adjective best describes your first semester in college?" Not surprisingly, the most frequent descriptors were busy, fun, stressful, and different. The paper concludes by discussing the implications of collecting this type of data as a form of early warning system.
\end{abstract}

Keywords: Student-Athletes; First-Year Experience; Adjustment to College; Early Alert

\section{INTRODUCTION}

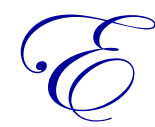

ach year universities in the U.S. collectively spend millions of dollars recruiting the highest caliber student-athletes from throughout the world to participate in a wide range of sports. National Collegiate Athletic Association (NCAA) Division I athletics are big business, and recruiting star players is imperative in amassing competitive teams that can attract sell-out crowds in huge stadiums and arenas. Although successful recruiting is essential to building winning teams, retaining these student-athletes should be an even higher priority - not merely for the sake of the team, but also because of the moral imperative to facilitate these students' intellectual as well as physical development. The vast majority of collegiate student-athletes will not have the opportunity to continue as professionals in their sport. The relationship between institutions and their studentathletes should be mutually beneficial.

For several decades colleges and universities in the U.S. have used various strategies known as "early warning systems" to assist in identifying students considered "at risk" of dropping out of college (Dwinell \& Higbee, 1990; Higbee \& Dwinell, 1990; Higbee, Dwinell, McAdams, GoldbergBelle, \& Tardola, 1991). Mechanisms such as progress reports from faculty to students and academic advisors (University of Minnesota, 2009; Wilmer, 2008) and tracking early indicators of success (Offenstein, Moore, \& Shulock, 2010) continue to be perceived as valuable tools in encouraging persistence and retention.

\section{EFFORTS TO IMPROVE RETENTION AMONG STUDENT-ATHLETES AT THE UNIVERSITY OF MINNESOTA, TWIN CITIES}

Participation in a first-year experience course is one potential indicator of student success (Offenstein et al., 2010). Freshman seminars can take many forms (Padgett \& Keup, 2011), and can have differing levels of impact for different student populations (Offenstein et al., 2010), but in general have been found to have a positive effect on retention. Ten years ago the University of Minnesota, Twin Cities introduced a required first-year experience course with content specifically designed for student-athletes as an initiative to enhance retention beyond the critical first year of college (Higbee \& Schultz, 2012). Attendance is taken in both the large lecture and smaller discussion section meetings each week. The first year that the course was offered, initial plans to take attendance in lecture by scanning students' university identification cards had to be abandoned because of the sporadic Internet access in the basement lecture hall of an outdated building that has since been demolished. Instead we introduced weekly question cards: 
Students picked up a blank card as they entered the lecture hall, where the week's question was projected on a screen. They then turned in the completed card to the faculty member or graduate teaching assistant (GTA), who stood at the doors as they left, thus ensuring that no student could submit an extra card for an absent friend. In addition to being credited for attending class, students received 5 points for submitting a card as long as the response reflected serious consideration of the question posed (Higbee \& Schultz, 2012, p. 353).

Most of the items developed for the weekly question cards were designed to address multiple purposes. Previous publications described the results for two of the questions posed each year: "What are the top three reasons (in priority order) why you are attending college?" (Schultz \& Higbee, 2007) and "What is the biggest unanswered question you have about college?" (Higbee \& Schultz, 2012). This paper summarizes student responses to another of the weekly questions. Responses to each of these questions had implications for student retention.

\section{METHOD}

The question for the final lecture of the semester was, "What adjective best describes your first semester in college?" Of the 122 students enrolled in the course, 109 consented to participate in this research study, and of those 103 were in attendance and responded to this question. The original data was confidential, but not anonymous; students identified themselves on the question cards in order to get credit for attending. The lack of anonymity also allowed us to use student responses as another potential early warning sign for students who might consider dropping out. However, after all responses were entered into an Excel spreadsheet the names and any other potential identifiers were eliminated, and the data set retained for purposes of this research is anonymous.

Specific adjectives in the data set were tallied and then synonyms were also grouped together. Some students chose to identify more than one adjective. In other cases, students used multiple adjectives in providing their reasoning for the initial adjective identified in their responses. Thus, there is overlapping data and the categories of adjectives are not discrete and mutually exclusive. The total number of adjectives reported in this paper is greater than the number of responding students.

\section{RESULTS}

In descending order of frequency, the specific adjectives used most often by students were as follow: (a) busy: 24 students, (b) stressful: 7, (c) fun: 7, and (d) different: 6 . Five adjectives were identified by four students each: new, challenging, overwhelming, hectic, and exciting. Adjectives used by three students included crazy, interesting, enjoyable, and fast. Hard, difficult, long, chaotic, adjusting, tough, and motivated were each used by two students to describe their first semester of college. Additional adjectives mentioned by one student each were raucous, structured, moralizing, emotional, shocking, active, awesome, flustered, thrilling, especial, confusing, fresh, enlightening, eye-opening, educating, unregrettable, insane, spacey, experience-filled, learning experience, good experience, experiment, strong, procrastinating, long, and lonely. In some cases the students chose an adjective to describe themselves during this critical period in their college experience.

\section{Seeking Balance: Busy Versus Stressful}

A different picture emerges when looking beyond the word counts and exploring how the students' responses might be grouped into thematic areas. The 29 students who used terms like busy or hectic described issues of school-sport balance differently than the 11 who found their first semester stressful or overwhelming. The following quote provides an example of a student who described the first semester as busy:

I would have to say busy would be the best adj. to describe my first semester. That's so because my days are nonstop from 5:45am to 10:30pm with going to practice, going to class, studying, \& working. I have found that I'm busier than I ever was in high school, \& in high school I was in numerous extracurricular activities. Also when I think about the last two months, I have probably gone out on the weekend only twice. Also I always talk to my parents each week and the only time that I can get a chance to call is either when I'm eating or at 10:00pm at night after I leave Bierman [academic center where required study hours for first-year student-athletes are held]. My schedule has just been so packed, that there is no way for me not to be busy \& any time that I do get to myself is rare \& not taken for granted. 
Another student wrote,

The adjective that best describes my first semester at University would have to be "busy." Busy basically describes everything that has happened to me up to this point since I arrived on campus. There has been so much that has happened and so much going on all around me that I hardly notice how quickly the year is going by. That is one of the best things about University; you are able to do so much and meet so many people, it is a wonderful experience!

Other students used synonymous terminology: "An adjective that best describes my 1st semester @ college would be hectic - but fun. Between schoolwork and practice, at times it was hard to find a relaxing moment, but I enjoyed every minute of it." There is a distinct contrast in tone between this student's description of the hectic pace of college life and that of the student who wrote, "really stressful at times trying to get good test scores in math and science, and try to keep up with wrestling." It might be anticipated that the student who chose the adjective active had focused primarily on being busy or getting lots of exercise, but that student wrote, "Active is my adjective that best describes my first half year of college. My first semester has been a daily routine and most of the time makes me tired or bored with myself." Another student whose description seemed to lean more toward stressful rather than merely busy said,

I would have to say flustered. It has been very busy since day one. Scheduling class, with hockey, and homework doesn't leave much time for a social life. I have learned to manage it and make time for things more recently however."

Yet another student wrote, "Chaotic_Classes were overwhelming and every day I felt like I was being pulled in a million directions." The five students who used the term overwhelming were not merely indicating that they were busy:

The adjective that best describes my first semester in college is "overwhelming." This adjective is appropriate because I have had an impossible schedule and have been under more stress than ever before. It's hard to believe how many activities I've been doing each day and the incredibly low amount of sleep that I've been getting and the insanely intense amount of physical activity I've been doing.

Other interesting choices that conveyed how fast-paced the semester had been were words like raucous, crazy, and insane. For example, one student exclaimed in capital letters: "CRAZY! Everything flew by so fast! I was pulled in a million places at once! Only word to explain . .." Other students who chose fast as their adjective wrote explanations like "Fast! I can't believe how quick it's going. Having a tight schedule, where I always have something to do, it makes the days go by fast." Another student explained,

Fast-This is the fastest that school has ever gone. I feel like I just came here a few weeks ago \& it has been two months! I have learned to manage my time better because it does go so fast.

Again, these answers are in sharp contrast to the responses of the students who described the semester as long:

Long, only because of a full, 12-week schedule of football. Body continues to get banged up and short time to recover. My body tends to have a hard time getting up in the morning. So hopefully in the off-season, with a little more rest my college experience would become a bit better.

The word I would choose is long. I would choose this word because it feels like it is taking forever for the semester end to come. I am also getting sick \& tired of being sick \& tired; that's why I pick the word long.

One of the more creative responses related to this theme was as follows:

The word that best describes my first semester is raucous. I pick this word because things are so crazy and move at such a fast pace. I also think that high school is at a slow pace so it didn't help prepare me for college. 


\section{Embracing The New And Different}

A total of 11 students chose the adjectives different, fresh, and new, and many others included these words elsewhere within their responses. One student wrote, "New - everything is a new experience and no previous experience has really helped me for all the things that have already happened." Another student shared, "New-it's a whole new experience! But it is also exciting and I love it. Living in dorms etc. is different of course than living at home; many aspects are simply different $\&$ new." The following quotes express three more students' perspectives on the newness of the college experience:

New: This semester has been a whole new experience for me. I have never known what it is like to live somewhere other than home and it has been very different to be away from my family. It has also been a new experience for me with studies. I have taught myself to work harder than I ever have and it has paid off. I am expecting new experiences and will now know how to handle them better.

Different: I have, so far, enjoyed my 1st semester in college, but everything about it is different than my life in high school except for balancing my school work, running, and social life. I have enjoyed the change and I was ready for it. Another thing that is really different for me is not seeing my family every day. I saw then this past weekend and I had a blast, but I hate it when they drop me off at the dorms and leave.

Different: Everything has been new to me. Nothing at all is as home. School, food, culture, friends and the list goes on. Even though it has been different and new for me it has been a lot of fun and it has strengthened me.

Thus, depending on the individual student, new or different can be interpreted in multiple ways-positive and negative: "Different is the word that best describes my first semester. There is not one thing in my life that is the same from my years in high school. I've had to change my lifestyle drastically." The perspective of the student who gave this explanation for different might be contrasted with that of the student who wrote, "fresh - because my schedule, living space, hockey, friends, classes, \& outlook on life is all fresh and new."

\section{Adjusting To College Life}

Students commented in different ways on how much more work college is than high school and how "tough" it is. One shared, "I would say my 1st semester word would be shocking. I was not expecting college to be so tough. I mean you cannot just cruise through your work like you do in high school." Two students used the word difficult:

Difficult. It has taken awhile to get the hang of things and how stuff works. When it comes to the classes they are quite difficult. I am starting to get the hang of things but I guess you could call it a learning experience.

My adjective is difficult. I choose this word to describe my experience because it is true. School, my sport, time management, my friends; they have all been difficult. Don't get me wrong, I am having the time of my life here, but there are some things that are a little more difficult than I was expecting.

It is clear that it is not only academics that these students are finding difficult. Time management and related themes appear frequently regardless of the adjective chosen. Students who used similar terms like hard and challenging also described multiple obstacles to overcome:

My first semester was pretty hard; it has led to a downfall for me. I have two F grades right now and it has not seemed harder as far as what they expect from me, but for some reason I just do not get good grades. So I would describe my semester of college as challenging!

I think the adjective that best describes my first semester of college is challenging. I've found that being a studentathlete pushes me to my mental and physical limits. And being this far from home has caused me to force myself to open up more socially. Not being able to see my family for a couple of months has also been really difficult. 
Two students addressed similar issues but focused on the adjustment itself instead of the difficulty. One commented, "Adjustment - I have had to learn how to not think about all of the homework and things I need to do, because than I get stressed." The other wrote, "Adjustment. College is a thing that you have to change and adjust to be successful in."

For two students successful adjustment seemed more elusive. One shared, "Lonely because I do not know very many people on campus and I do not really have anything to do except basically homework." The other wrote, "EMOTIONAL: I have had many up's \& down's this semester. Getting used to swimming and classes was a huge adjustment. Above all that I had to get used to being away from home and doing this all without my parents."

\section{Enjoying The College Experience}

Quite a few students indicated that they were enjoying the college experience: "Enjoying, I used this word because college has been enjoying [sic] so far mainly because of the down time you have to relax during the day. Classes haven't been too bad either." Seven students selected the word fun to describe their first semester. One student exclaimed, "I would say 'fun' because it has been a blast since I got here! It has been very different but I really like the change." Other students commented,

FUN! I have had a lot of fun since I have been here. It is a really new experience for me to be in Minnesota. I have met a lot of new people. Sports has been a lot of fun and my classes and teachers are all really nice.

The adjective that best describes my 1st semester at college is fun. I have had lots of fun with hockey, as well as college life in general. I also really enjoy the people I live within the dorms.

Four students described their first semester as exciting: "Exciting - my first semester was exciting for me to start and go through because of the new experiences that I have been able to see." It was not unusual for students to use both exciting and fun in their responses: "I would describe my first semester as exciting. I have been extremely busy with school and football. Although I've been busy, I've also had a lot of fun. It's been fun meeting new people and new teammates." It is rewarding to know that some students articulated that learning was exciting:

Exciting is a good adjective to describe my first semester because lots of the activities and events can be exciting. Also, racing in cross country is exciting. Meeting new people can be a lot of fun. Also, learning new material is informative and exciting.

The previous quote is just one of several in which the word "also" is repeated because there is more and more for the student to say.

One student felt compelled to choose the adjective so overused by many young people today: "Awesome! - because I have really enjoyed every moment of it, learned many new things and met many new and interesting friends." Another chose thrilling, while one wrote,

The adjective that best describes this semester is especial, because it has been a complete change for me. Each day that I am here I learn something as an experience for my life, so I feel like this semester is very different from others of my life and I consider it very very especial.

\section{Focusing On Getting The Job Done}

A number of students addressed "taking care of business" but from different perspectives. An interesting choice of adjective was "Structured: Almost every day is structured from morning to night for me." Two students wrote about being motivated:

Motivated: I am trying to get off to the best start that I can, I am hoping to get the best grades I can. Therefore I am hoping by getting off to a good start I will end good. 
The adjective that best describes myself would have to be "motivated." I feel that this is the best adjective because I am a person who is determined to finish whatever I start. Another adjective to describe my 1st semester is college would have to be "experiment." I feel that everything up till now, I have been experimenting to see what works \& what doesn't work.

Although choosing the descriptor enlightening, being motivated was also on the mind of another student: "Enlightening, because it is a new and different experience living alone, being motivated to do my work on my own, and participating in a D-1 sport." In contrast, one student wrote, "An adjective that describes me for my first semester in college is procrastinator because I found myself waiting til the last minute to do my assignments and projects." Somewhere in between the motivated students and the procrastinator is the student who responded,

Spacey? It took me awhile to adjust to how everything was assigned online and I tried to get used to checking online everyday \& taking timed quizzes \& doing homework online, but now that I am used to it I enjoy the flexibility of it.

\section{Gaining Experience}

Several students used the word experience as part of their descriptor, as in this example: "Good experience because it has been fun, but at the same time it has been challenging. I think it has also been a 'wake up' call for what the real world is going to be like." Other students wrote, "learning experience: I have learned a lot about myself, others, and college life" and "experienced filled: I have just learned so much and done so many new things."

\section{Developing Values}

Many of the themes emerging from these responses seem to go hand-in-hand with Chickering's (1969; Chickering \& Reisser, 1993) seven vectors of college student development and other theories of identity development. This is particularly true of the responses related to developing values and then upholding them - what Chickering would refer to as developing integrity:

Moralizing: Because being in college and being independent and being able to make my own decisions has taught me new morals. Being put in new situations that may make me uncomfortable teaches me valuable life lessons.

Eye-opening because you realize that what everybody says about college is really there; the partying, drinking, dedication to school and athletics. It makes it a very hard transition when you don't drink and don't like to party a lot. You have to be able to find yourself and stick strong to your beliefs, which is never easy when you are in the minority.

A positive adjective that describes me in my first semester is strong. It takes a strong person to adjust to the home work or school load and keep up good grades. Also to keep up w/ doing well w/ track. Yea, I have doubts, but I need to talk to myself and tell myself I am strong. College has challenged me also to be strong with my morals.

\section{DISCUSSION AND IMPLICATIONS}

As mentioned previously, although identifying one specific adjective, many students used a number of others in their explanations and some of these descriptors such as fun, busy, and stressful emerged frequently within the data set. Meanwhile, some students could not limit themselves to a single adjective, and their use of two or more sent mixed messages about how they perceived their first semester of college. For example, one student wrote,

Thrilling, Educating, Confusing. My first semester of college has been an experience. Baseball has gone so well it has been everything I had hoped for. School has also been good. At first I was overwhelmed but I have settled in nicely. I have studied hard, but it has benefited me! Still I am adjusting to being away from home. But overall all is well!

In fact, this example may be more indicative of students' actual perceptions; surely most students experienced both highs and lows. This student seems invested in reassuring the faculty and staff involved in teaching this first-year 
experience course that despite challenges, there have also been many achievements and "all is well." Another student wrote, "Un-regrettable - meet a lot of people, had a lot of fun, getting good grades, haven't screwed up too bad yet." For other students, including those who chose adjectives like lonely, emotional, or overwhelming, a different message is conveyed; these were students who might need additional supports to assist in overcoming their challenges (Sanford, 1967).

For faculty and staff working with student-athletes at the University of Minnesota there are many data points that can contribute to an early warning system for identifying students who may be at risk of dropping out. Mid-term alerts (University of Minnesota, 2009) and other forms of communication among faculty, academic advisers, and athletic association counselors, mentors, and tutors focus primarily on academic indicators, but these factors are but one of the many causes of attrition (Astin, 1975; Tinto, 1987). The use of the weekly question cards described in this paper and elsewhere (Higbee \& Schultz, 2012; Schultz \& Higbee, 2007) requires relatively little effort, especially when done within the context of a first-year experience course, and can provide additional information that may not be captured otherwise — stress, loneliness, "sick \& tired of being sick \& tired." Educators should take advantage of opportunities like these to become better acquainted with students. Although this paper focused on responses from first-year student-athletes, we should be equally invested in the success of all students at the institution.

\section{AUTHOR INFORMATION}

Jeanne L. Higbee has worked in higher education since 1974, first in student affairs, and since 1985 in faculty positions. She currently serves as Professor and Director of Graduate Studies for the Department of Postsecondary Teaching and Learning in the College of Education and Human Development at the University of Minnesota, Twin Cities. She is a 2011 recipient of the Horace T. Morse-University of Minnesota Alumni Association Award for Outstanding Contributions to Undergraduate Education as well as the University of Minnesota Intercollegiate Athletics Department's Tom H. Swain Campus Recognition Award honoring her commitment to the academic success of studentathletes. E-mail: higbe002@umn.edu (Corresponding author)

Jennifer L. Schultz is an Associate Professor in Human Resource Management (HRM) for The College of Management at Metropolitan State University in Minneapolis, Minnesota. She serves as the Curriculum Coordinator for the undergraduate HRM program and teaches graduate and undergraduate courses in management and HRM. She earned her Ph.D. from the University of Minnesota, Twin Cities, where she served as the graduate teaching assistant for the course described in this paper. E-mail: Jennifer.Schultz@metrostate.edu

\section{REFERENCES}

1. Astin, A. W. (1975). Preventing students from dropping out. San Francisco, CA: Jossey-Bass.

2. Chickering, A. W. (1969). Education and identity. San Francisco, CA: Jossey-Bass.

3. Chickering, A. W., \& Reisser, L. (1993). Education and identity ( $2^{\text {nd }}$ ed.). San Francisco, CA: Jossey-Bass.

4. Dwinell, P. L., \& Higbee, J. L. (1990). The role of assessment in predicting achievement among high risk freshmen: A bibliographic essay. Journal of Educational Opportunity, 5(1), 29-34.

5. Offenstein, J., Moore, C., \& Shulock, N. (2010). Advancing by degrees: A framework for increasing college completion. Washington, DC: The Education Trust.

6. $\quad$ Higbee, J. L., \& Dwinell, P. L. (1990). The high risk student profile. Research \& Teaching in Developmental Education, 7, 55-64.

7. Higbee, J. L., Dwinell, P. L., McAdams, C. R., GoldbergBelle, E., \& Tardola, M. E. (1991). Serving underprepared students in institutions of higher education. Journal of Humanistic Education and Development, 30, 73-80.

8. Higbee, J. L., \& Schultz, J. L. (2012, March). Responding to the concerns of student-athletes enrolled in a first-year experience course. Paper presented at the Clute Institute International Conference, Bangkok, Thailand. Retrieved from http://conferences.cluteonline.com/index.php/IAC/2012BK/paper/view/1089

9. Padgett, R. D., \& Keup, J. R. (2011). 2009 national survey of first-year seminars: Ongoing efforts to support students in transition. Columbia, SC: University of South Carolina, National Resource Center for the First-year Experience and Students in Transition. 
10. Sanford, N. (1967). Where colleges fail: The study of the student as a person. San Francisco, CA: JosseyBass.

11. Schultz, J. L., \& Higbee, J. L. (2007). Reasons for attending college: The student point of view. Research \& Teaching in Developmental Education, 23(2), 69-76.

12. Tinto, V. (1987). Leaving college: Rethinking the causes and cures of student attrition. Chicago, IL: The University of Chicago Press.

13. University of Minnesota. (2009). Administrative policy: Providing mod-term alerts on academic performance. Retrieved from

http://www.policy.umn.edu/Policies/Education/Education/MIDTERMACADPERFORMANCE.html\#100

14. Wilmer, E. (2008). Student support services for the underprepared student. Inquiry, 13(1), 5-19. 